\title{
Missing categories in open space planning
}

\author{
K. Bomans, V. Dewaelheyns \& H. Gulinck \\ Department of Earth and Environmental Sciences, \\ Katholieke Universiteit Leuven, Belgium
}

\begin{abstract}
Planning for open space is strongly rooted in conventional categories of land use and land cover (such as agriculture, urban and forest). Objectives are set and measures are taken to, for example, preserve biodiversity, enlarge the area for forests, ensure there is enough land for cost-effective professional agriculture and maintain a margin for housing and industrial development. However, in recent years there has been an emerging attention for questioning these standard categorizations for several reasons, such as the upsurge of newcomers in land use, the differentiation of standard categories, such as tourism/recreation, agriculture and water management and the emergence of new functions, such as carbon sequestration and wind energy.

This paper pays attention to the spatial importance of two rather neglected categories of open space: (i) gardens and (ii) grassland for horses. Gardens, especially private gardens, tend to be ignored because they are considered as a part of the urban fabric. 'Grassland for horses' disappears somewhere within the category of agriculture, although it is also strongly linked with the urban context. Using different methods, including fieldwork, interpretation of aerial photographs and regression analysis, a quantification of these categories is made for the Northern part of Belgium, Flanders. From this, suggestions are made about the role of these categories in sustainable open space planning.
\end{abstract}

Keywords: open space, garden, grassland for horses, spatial planning.

\section{Introduction}

The term open space has different meanings that relate to rurality, non-built soils, visual openness or access for people and activities. In this paper, open space is defined as "the totality of land units with mainly non-built soils" and therefore encompasses a wide range of categories. Most common are agriculture, 
forest and nature as the major open space categories, used in a huge number of studies and monitoring programs concerning open space, land use and land use change. However, there is a risk of the remaining land being stuck in standard categories for open space and so we may remain unaware of opportunities, problems or changes that are largely a response to "unconventional" societal demands on land. In recent years, there has been an emerging attention for questioning these standard categorizations for several reasons, such as the upsurge of newcomers in land use, the differentiation of standard categories, such as tourism/recreation, agriculture and water management and the emergence of new functions such as carbon sequestration and wind energy. These observations lead to the definitions of gaps in land use research agendas (Holmes [15]), to re-questioning the typologies and classifications (Alverez-Lopez et al. [1]) or to new overarching concepts of land use such as neorurality (Gulinck [14]). This paper is intended to substantiate this critical view on open space with quantitative data. Therefore an investigation was made on the spatial importance of two rather neglected categories of open space in the Northern part of Belgium (Flanders): (i) gardens and (ii) grassland for horses.

Existing literature on the two topics is explored and presented in Section 2. Section 3 describes the different methods used, including fieldwork, interpretation of aerial photographs and regression analysis for the study area of Flanders. Next, two main questions are answered in the 'Results' (Section 4) and in the 'Discussion' (Section 5): (1) what is the spatial importance of those two categories and (2) can they be considered as missing categories in open space planning?

\section{Literature survey}

\subsection{Functionalities and spatial importance of gardens}

It is more and more recognized that gardens are vital in the conservation of biodiversity in urban areas (Tratalos et al. [34]; Gaston et al. [11]; Gaston et al., [12]). Gardens can also be a main source of invasive and exotic flora (Marco et al. [19]), having an impact on the biodiversity in urban areas as well as in the rural. Next to this, other environmental functionalities of gardens have raised the interest of researchers. In particular, the use of pesticides and herbicides (Grey et al. [13]; Karr et al. [16]; Dewaelheyns and Gulinck [8]), the use of water (Syme et al. [29]; Dewaelheyns and Gulinck [8]) and organic waste (Dewaelheyns and Gulinck [8]) are important points of concern at the scale of one garden. On a broader scale, a green garden structure can play a crucial positive role in the ecological performance of urban areas, in the context of better climatic conditions, more biodiversity, less pollution, less water run-off and more carbon sequestration (e.g. Bolund and Hunhammar [3]; Pauleit and Duhme [25]; Gaston et al. [11]; Gaston et al. [12]; Barbosa et al. [2]; Tratalos et al. [31]). Besides the ecological importance of gardens, as mentioned above, gardens contribute to public health and the liveability of urban areas, although the information on this topic is limited. According to Dunnett and Qasim [9], gardens contribute to a 
better well being, mostly because of the pleasant environment, the possibility of relaxing, the pleasure and satisfaction of gardening and the direct contact with 'nature'. Health effects of gardens are investigated by Nielsen and Hansen [23], who conclude that easy access to green areas reduces stress. Finally, the economical importance of gardens may not be neglected. Dunnett and Qasim [9] indicate that the British market in plants and requirements related to gardens represents a substantial capital. Construction and maintenance of gardens gives an income to 3100 people in Flanders (Fedagrim [10]), a number that is still growing.

Despite all this existing knowledge on the importance of gardens in an ecological, social as well as an economical context, Perry and Nawaz [26] and Mathieu et al. [20] indicate that little information is available on the extent of private gardens. Lang et al. [17] point to the fact that quantitative information on green structures and the dispersion of green areas is essential for sustainable planning. Existing information on the spatial characteristics of gardens is mainly linked to urban areas. According to Tratalos et al. [31], for example, gardens are the most dominant land cover class in urban areas of Sheffield, Edinburgh, Glasgow, Leicester and Oxford (UK). However, none of those studies has led to a reference map indicating the spatial distribution of gardens for a bigger area (e.g. a country).

\subsection{Functionalities and spatial importance of horses}

In history, horses played an important economical role not only as draught horses in the agricultural sector, but also in mines and harbours. After WWII those horses were pushed aside by motorization (e.g. Saifi and Drake [28]) and the economical importance of the horse-sector has shifted to the production, the trade and/or the use of breeders and riding animals. According to Viaene et al. [35] and the Policy Research Cooperation [27], the horse-sector in Flanders has a significant economical importance in production, processing and delivery. The sector realizes a yearly added value of 215 million $€$ in the Flemish economy and realizes employment for more than 3500 full time equivalents (Policy Research Cooperation [27]).

More and more people keep horses for pleasure. Already in 1986, Daniels discussed the growing number of hobby farms in the urban-rural environment of Oregon. In the study of Busck et al. [5] the number of "hobby-related" animal units (one unit is equal to one cow) around Copenhagen grew from 0.02 to 0.1 per hectare in the period 1984-2004. According to Törn et al. [30], horse riding is a recreational form that is gaining importance in Finland. Viaene et al. [35] point to the growing interest in Belgium for recreational horse riding. The same can be said about Sweden, where Myhr and Johansson [22] emphasize in this context the proximity of cities. Verburg et al. [34] joins them by asserting that in the peri-urban regions of Western Europe, large areas of grassland on former agricultural land are now used for horse holdings. This 'horsification' was also mentioned by Vejre [33] as a striking evolution in Denmark and also van der Windt et al. [32] indicate a strong growth of horse holdings in the Netherlands both for professionals and individual persons. 
Different perceptions exist on this evolution of horsification. According to van der Windt et al. [32] horses can give the countryside a new economical and recreational strength, they can revive the landscape and give new opportunities to farmers. Other authors mention the negative aspects of this evolution, including the ecological consequences of horse riding (Törn et al. [30]), a growth of artificial elements in the landscape (Verburg et al. [34]) and the threat to agriculture (Daniels [7]).

Despite this growing importance of horses, little information is available on the number of horses or on their spatial dispersion and importance. According to van der Windt et al. [32], the Netherlands count about 400000 horses. Viaene et al. [35] estimated the number of horses, ponies and donkeys in Belgium at 160 000 , taking up an area of 69500 ha. These are, however, rough estimations and Verburg et al. [34] stress the fact that in many countries hobby-horses are not part of the official agricultural statistics, which makes this type of land use largely unknown. In Belgium, Since July 2008, owners of a horse are obliged to register their horse(s). At the end of 2008, 90000 horses were registered for Flanders, although expert opinions estimate the real number to be 150000 .

\section{Materials and methods}

To explore the distribution and spatial importance of gardens and grassland for horses, case study research is confronted with existing census data for the study area Flanders. The case study research differs by topic, depending on the goals, possibilities and practical constraints (like time and available data) related to each topic.

\subsection{Gardens}

\subsubsection{Case study research}

Since there is no detailed information available on the extent of the individual gardens in Flanders, data are gathered by means of the Area Frame Sampling technique. Within a stratified random sample of 60 segments $(500 \mathrm{~m} \times 500 \mathrm{~m})$, scattered all over Flanders, garden areas and the related houses are identified on digital aerial photographs from 2002 (scale 1:12 000, OC-GIS Vlaanderen, 2005) and digitized in ArcView 3.2. For complex and diverse landscapes like Flanders, 25 ha is a commonly used study unit (Bunce et al. [4], Cooper and McCann [6]). A One-Way ANOVA statistical test resulted in a p-value of $0.878(\alpha=0.05)$, whereby the null-hypothesis states that there are no significant differences between the mean area of gardens in different tested sample sizes. Therefore, a sample of 60 segments was accepted to be big enough compared to alternative sample sizes of 80,100 and 400 segments.

\subsubsection{Confrontation with census data}

The result of the photo-interpretation is confronted with existing census data from the National Geographical Institute in Belgium (NGI [36]), being a 
topographic land use map (resolution $0.66 \mathrm{~m}$ ) for Flanders and the Brussels region, containing the land use class 'garden'. The census data include the Brussels region although the analysis is only performed for Flanders. An error analysis verifies if there is a systematic deviation of the census data compared to the situation on the aerial photographs. If so, the formula for this systematic deviation is identified, using linear regression. This leads to a more correct estimation of the spatial importance of the garden area in Flanders and to an improved map, showing the spatial distribution of gardens.

\subsection{Grassland for horses}

\subsubsection{Case study research}

Grasslands for horses cannot be distinguished from other grasslands using aerial photographs or satellite images. Therefore, those grasslands are mapped on the field in six municipalities in Flanders, differing in degree of built area, population density, agricultural activities, forest area and/or fragmentation of the agricultural land. For each municipality, $10 \%$ of the area is inventoried, using segments of $700 \mathrm{~m} \times 700 \mathrm{~m}$. Referring to O'Neill et al. [24] a segment needs to be at least two to five times the inventoried patch ( 21 ha in this case, being the maximum agricultural parcel identified in the investigated area). Grasslands for horses are recognized by the presence of one or more horses, by typical 'horseattributes' (like a fence in wood or a horse shelter) or by the confirmation of local inhabitants. The fieldwork is digitized in ArcView 3.2.

\subsubsection{Confrontation with census data}

The spatial distribution of horses in Flanders can be visualized at the level of a municipality, using census data from the Belgian Confederation for Horses [37]. By means of a well-considered estimation of the horse-density, the area derived from the census data can be compared to the area identified in the case studies to estimate the actual spatial importance of grassland for horses in Flanders.

\section{Results}

\subsection{Gardens}

For the 60 segments, a linear regression analysis between the census data of the National Geographic Institute [36] and the data from the aerial photographs, showed a systematic over-estimation of the census data (see Figure 1). In 19 of the 60 segments this over-estimation of the total garden area was more than 5\%. Several categories of land use, like holes for the exploitation of clay, farms and agricultural land, forest and forested parts of parcels, fallow (parts of) parcels and parcels for hobby farming were mistakenly classified as 'garden' on the land use map. Using the linear regression equation to improve the land use map, the total garden area in Flanders (not including the Brussels region) was calculated to be $8.4 \%$ (or $1083 \mathrm{~km}^{2}$ ) of the Flemish territory. 


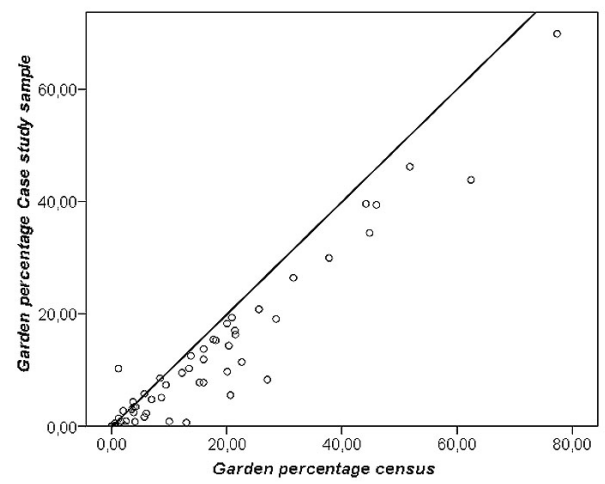

Figure 1: Census data vs. data from the aerial photographs, showing an overestimation in garden percentage by the census data (the line on the graph shows a perfect fit).

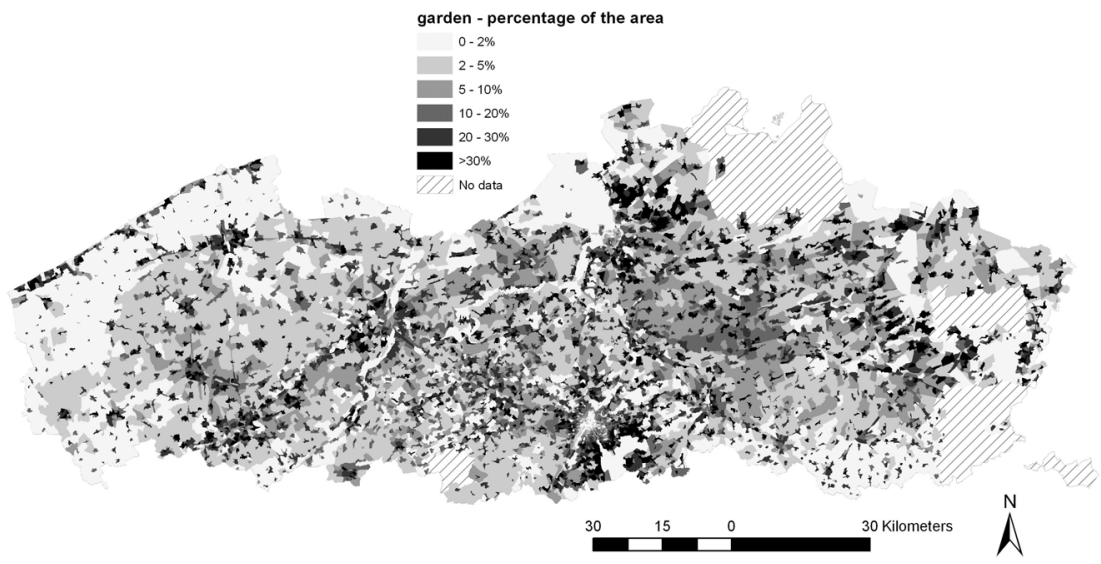

Figure 2: $\quad$ Percentage of garden area in Flanders and the Brussels region per statistical sector, based on the NGI census data [36] and the analysis of aerial photographs.

The spatial distribution of the gardens is calculated per statistical sector and displayed in the map in figure 2. A statistical sector is a small administrative unit for which the Belgian National Statistical Institute distributes different types of statistical data.

The map shows a concentration of garden area especially around city and town centres (e.g. Brussels, Ghent, Bruges, Antwerp and Leuven). This corresponds to the conclusions of Gaston et al. [11], Gaston et al. [12], Loram et al. [18] and Tratalos et al. [31] that gardens take up an important part of urban areas. Also the coastline is characterized by a concentration of gardens. Furthermore, ribbon development along main traffic axes brings along linear concentrations of garden area. Regions with a high agricultural area remain for the most part free of gardens. 


\subsection{Grassland for horses}

According to the census data received in September 2008, there are around 76600 horses in Flanders. Assuming a horse-density of 0.5 ha per horse (Viaene et al. [35]), this means an area of 38300 ha. However, in the case study research, the area of grassland used for horses was estimated to be at least $5.1 \%$ of the total area. Applying this percentage to Flanders, 69300 ha of the Flemish territory is used as grassland for horses. This means that the number of horses is strongly underestimated by the census data. This was to be expected, since the data-collection started for the first time in 2008. Between the beginning of September and the end of December 2008, the number had already grown to \pm 90 000 and experts estimate the real number to be even much higher.

Assuming a uniform error of underestimation among the different municipalities, the spatial distribution of horses in Flanders is visualized in Figure 3. Horses seem to be more concentrated in urbanized areas, with a highly fragmented agriculture.

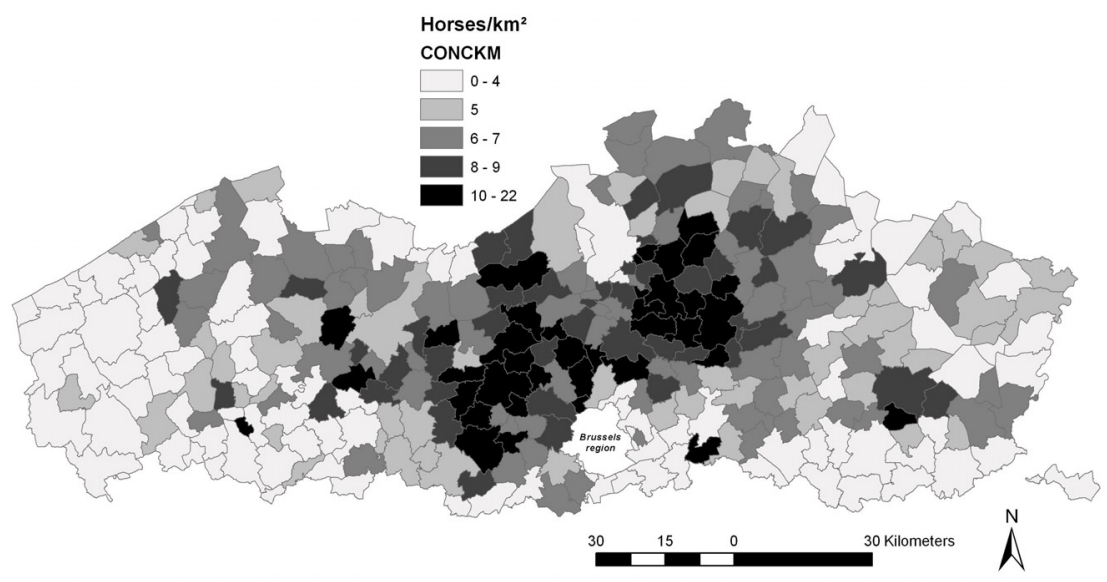

Figure 3: Estimation of horse-density in Flanders, based on data from the Belgian Confederation for Horses [37].

\section{Discussion}

\subsection{The spatial importance of gardens and grassland for horses is underestimated}

Both gardens (8.4\%) and grassland for horses (5.1\%) encompass a significant area of the Flemish territory. A total area of $\pm 1800 \mathrm{~km}^{2}(13.5 \%)$ seems to disappear somewhere in the land use statistics. Although the National Geographical Institute mapped already in 2004 an (overestimated) garden-area of $14 \%$, this percentage was never mentioned or calculated before. Before 2008, no reliable data existed concerning horses, which made it a 'ghost-category' of the 
open space. Despite their spatial importance, gardens and grassland for horses remain two of the most scarcely studied and documented land use categories.

\subsection{Gardens and grassland for horses as missing categories in spatial planning}

Gardens make up an important 'green' part of urban fabric. Underlining the spatial importance of gardens in the urban area is an important renewed basic principle to define an urban area, which is traditionally categorized together with 'buildings, pavement and a high population density'. According to the Flemish spatial planning documents, the urban area is characterized by a high concentration of people, activities and functions (Ministerie van de Vlaamse gemeenschap [21]). Green areas or open space within the urban area are rarely mentioned in definitions of urban areas although they can be important contributors to sustainability in a social, psychological and environmental way (see also Chapter 2). Moreover, since Flanders is characterized by a spatial pattern of numerous towns, scattered houses and urbanized villages, gardens are not only to be mentioned in an urban (city) context. They appear throughout the Flemish landscape and are therefore important spatial elements to consider in urban as well as open space planning.

By ignoring grassland for horses as an important element for open space planning, chances for open space may be passed by or problems may rise. The first relates to the economical importance of the sector and recreational opportunities (Policy Research Centre 27; van der Windt et al. [32]; Viaene [35]). The latter includes the growth of artificial elements in the landscape (Verburg et al. [34]) and conflicts with the agricultural (Daniels [7]) or the nature sector (Törn et al. [30]).

\section{Conclusion}

The spatial importance of both gardens and grassland for horses and the lack of interest for both categories was clearly indicated in this paper. They deserve more 'space' on the research and the political agenda. However, it is understandable that up till now, both gardens and grassland for horses were not included in spatial planning policies. The diversity in gardens/horse-holdings and the number of owners make it difficult to define and quantify those categories. However, interest is rising from an academic and a political perspective, especially in strongly urbanizing areas.

\section{References}

[1] Alvarez-Lopez, C., Riveiro-Valiño, J. \& Marey-Pérez, M., Typology, classification and characterization of farms for agricultural production planning. Spanish Journal of Agricultural Research, 6(1), pp. 125-136, 2008. 
[2] Barbosa, O., Tratalos, J.A., Armsworth, P.R., Davies, R.G., Fuller, R.A., Johnson, P., et al., Who benefits from access to green space? A case study from Sheffield, UK. Landscape and Urban Planning, 83(2-3), pp. 187195, 2007.

[3] Bolund, P. E. \& Hunhammar, S, Ecosystem Services in Urban Areas. Ecological Economics, 29(2), pp. 293-301, 1999.

[4] Bunce, R. G. H., Metzger, M. J., Jongman, R. H. G., Brandt, J., De Blust, G., Elena-Rossello, R., et al, A Standardized Procedure for Surveillance and Monitoring European Habitats and Provision of Spatial Data. Landscape Ecology, 23(1), pp. 11-25, 2008.

[5] Busck, A.G., Kristensen, S.r.P., Prøstholm, S.r. \& Primdahl, J.r., Porous landscapes - The case of Greater Copenhagen. Urban Forestry \& Urban Greening, 7(3), pp. 145-156, 2008.

[6] Cooper, A. \& McCann, T. Habitat change in the Northern Ireland countryside: summary report of the Northern Ireland countryside survey, 2000. Environment Heritage Service, Department of the environment for the Northern Ireland: Belfast, 2002.

[7] Daniels, T.L. Hobby farming in America: Rural development or threat to commercial agriculture? Journal of Rural Studies, 2(1), pp. 31-40, 1986

[8] Dewaelheyns, V. \& Gulinck, H. Input en output in privétuinen (Input and output in private gardens). Milieurapport Vlaanderen, Vlaamse Milieumaatschappij, Brussels, 2008, http://www.milieurapport.be/Upload/ main/miradata/MIRA-T/01_sectoren/01_02/huis_O\&O_03.pdf) (in Dutch).

[9] Dunnett, N. \& Qasim, M., Perceived benefits to human well-being of urban gardens. Hort Technology, 10(1), pp. 40-45, 2000.

[10] Fedagrim v.z.w., Economisch dossier 2006 (Economical file 2006), http://www.fedagrim.be/pdf/ED2006_NL.pdf, 2006 (in Dutch).

[11] Gaston, K. J., Smith, R. M., Thompson, K. \& Warren, P. H., Urban Domestic Gardens (II): Experimental Tests of Methods for Increasing Biodiversity. Biodiversity and Conservation, 14(2), pp. 395-413, 2005a.

[12] Gaston, K. J., Warren, P. H., Thompson, K. \& Smith, R. M., Urban Domestic Gardens (IV): the Extent of the Resource and Its Associated Features. Biodiversity and Conservation, 14(14), pp. 3327-3349, 2005 b.

[13] Grey, C. N. B., Nieuwenhuijsen, M. J., Golding, J. \& Alspac Team, Use and Storage of Domestic Pesticides in the UK. Science of the Total Environment, 368(2-3), pp. 465-470, 2006.

[14] Gulinck, H, Neo-rurality and multifunctional landscapes (Chapter 1). Multifunctional landscapes, Volume 1. Theory, values and history, ed. J. Brandt \& H. Vejre, Southampton: WIT Press, pp. 63-74, 2004.

[15] Holmes, J., Impulses towards a multifunctional transition in rural Australia: Gaps in the research agenda. Journal of Rural Studies, 22(2), pp. 142-160, 2006.

[16] Karr, C. J., Solomon, G. M. \& Brock-Utne, A. C., Health Effects of Common Home, Lawn, and Garden Pesticides. Pediatric Clinics of North America, 54(1), pp. 63-80, 2007. 
[17] Lang, S., Jekel, T., Hölbling, D., Schöpfer, E., Prinz, T., Kloyber, E., et al. Where the grass is greener - mapping of urban green structures according to relative importance in the eyes of the citizens. First EARSel workshop of the SIG urban Remote Sensing. Humboldt-Universität zu Berlin, 2-3 March 2006, http://www.earsel.org/workshops/SIG-URS-2006/PDF/Session2_ LANG.pdf, 2006.

[18] Loram, A., Tratalos, J., Warren, P. H. \& Gaston, K. J., Urban Domestic Gardens (X): the Extent \& Structure of the Resource in Five Major Cities. Landscape Ecology, 22(4), pp. 601-615, 2007.

[19] Marco, A., Dutoit, T., Deschamps-Cottin, M., Mauffrey, J.-F., Vennetier, M. \& Bertaudičre-Montes, V., Gardens in urbanizing rural areas reveal an unexpected floral diversity related to housing density. Comptes Rendus Biologies, 331(6), pp. 452-465, 2008.

[20] Mathieu, R., Freeman, C. \& Aryal, J., Mapping Private Gardens in Urban Areas Using Object-Oriented Techniques and Very High-Resolution Satellite Imagery. Landscape and Urban Planning, 81(3), pp. 179-192, 2007.

[21] Ministerie van de Vlaamse Gemeenschap. Ruimtelijke Structuurplan Vlaanderen (Spatial Structure Plan Flanders). Integrale versie. Ministerie van de Vlaamse Gemeenschap: Brussels, 1997 (in Dutch)

[22] Myhr, U. \& Johansson, R., EcoEffect for outdoor environments, the process of tool development. Environmental Impact Assessment, 28(7), pp. 439454, 2008.

[23] Nielsen, T. S. \& Hansen, K. B., Do Green Areas Affect Health? Results From a Danish Survey on the Use of Green Areas and Health Indicators. Health \& Place, 13(4), pp. 839-850, 2007.

[24] O’Neill, R.V., Hunsaker, C.T., Timmins, S.P., Jackson, B.L., Jones, K.B., Riiters, K.H., et al., Scale problems in reporting landscape pattern at the regional scale. Landscape Ecology, 11(3), pp. 169-180, 1996.

[25] Pauleit, S. E \& Duhme, F., Assessing the Environmental Performance of Land Cover Types for Urban Planning. Landscape and Urban Planning, 52(1), pp 1-20, 2000.

[26] Perry, T. \& Nawaz, R., An Investigation Into the Extent and Impacts of Hard Surfacing of Domestic Gardens in an Area of Leeds, United Kingdom. Landscape and Urban Planning, 86(1), pp. 1-13, 2008.

[27] Policy Research Cooperation (2008). Een analyse van het economische en sociaal-maatschappelijke profiel en belang van de Vlaamse paardenhouderijen. (An analysis of the economic and social profile and importance of Flemish horse-holdings). Presentation workshop, 16 October 2008, Brussels, http://v.vlaanderen.be/nlapps/data/docattachments/ studie_paarden.pdf, 2008 (in Dutch).

[28] Saifi, B. \& Drake, L., Swedish agriculture during the twentieth century in relation to sustainability. Ecological Economics, 68(1-2), pp. 370-380, 2008. 
[29] Syme, G. J., Shao, Q. X., Po, M. \& Campbell, E., Predicting and Understanding Home Garden Water Use. Landscape and Urban Planning, 68(1), pp. 121-128, 2004.

[30] Törn, A., Tolvanen, A., Norokorpi, Y., Tervo, R. \& Siikamäki, P. Comparing the impacts of hiking, skiing and horse riding on trail and vegetation in different types of forest. Journal of Environmental Management, in press, Corrected Proof, doi:10.1016/j.jenvman. 2008.08.014.

[31] Tratalos, J., Fuller, R. A., Warren, P. H., Davies, R. G. \& Gaston, K. J., Urban Form, Biodiversity Potential and Ecosystem Services. Landscape and Urban Planning, 83(4), pp. 308-317, 2007.

[32] Van der Windt, N.P., Olde Loohuis, R.J.W. \& Agricola, H.J., De paardenhouderij in beeld, een verkenning naar de landschappelijke verschijningsvorm van de paardenhouderij (horse-holdings, an exploration of their manifestation in the landscape), Alterra-rapport 1444: Wageningen: Alterra, 2007 (in Dutch).

[33] Vejre, H. Models for safeguarding urban fringe open landscapes the balance between public and private. Case study of management models for urban green space around Copenhagen. Proc. of the Conference Rurality near the City, eds. V. Dewaelheyns \& H. Gulinck, KULeuven: Leuven, www.ruralitynearthecity.be, 2008.

[34] Verburg, P.H., van de Steeg, J., Veldkamp, A. \& Willemen, L. From land cover change to land function dynamics: A major challenge to improve land characterization. Journal of Environmental Management, in press, Corrected Proof, doi:10.1016/j.jenvman.2008.08.005.

[35] Viaene, J., Gellynck, X. \& De Belder, T. Het economische belang van de paardensector (The economical importance of horses. Het economisch belang van de paardensector). University of Ghent, Faculty of agricultural and biological sciences: Ghent, 2003 (in Dutch).

[36] National Geographic Institute of Belgium (2004). Topographic land use map. Raster version, resolution $0.66 \mathrm{~m}$. Brussels.

[37] Belgian Confederation for Horses (2008). Registration of horses in Flanders. Number of horses per sanitar responsible at municipality level. Service for the identification of horses, Korbeek-Lo. 